\title{
МЕТОД ОЦІНКИ ЕФЕКТИВНОСТІ КОМПРЕСІЙНОЇ ЕЛАСТОГРАФІЇ БІОЛОГІЧНИХ ТКАНИН В ЗАЛЕЖНОСТІ ВІД ГЛИБИНИ ЇХ РОЗТАШУВАННЯ
}

\author{
Міщенко Ю.С., магістрант \\ sokol7romashka@gmail.com \\ Факультет біомедичної інженерії \\ Національного технічного університету \\ «Київський політехнічний інститут імені Ігоря. Сікорського», \\ м. Київ, Україна \\ Тарасова Л.Д., доц., к.Т.н. \\ larisa.tarasova.dmitrievna@gmail.com \\ Кафедра біомедичної інженерії \\ Національного технічного університету \\ «Київський політехнічний інститут імені Ігоря. Сікорського», \\ м. Київ, Україна
}

Реферат - Запропоновано метод оцінки ефективності компресійної еластографії біологічних тканин в залежності від глибини їх розташування, який дозволяє дослідити якість зображення та диферениіацію тканин від глибини розміщення тест-об'єкту, типу датчиків та діапазону частот сканування. Отримані дані розширіють можливості застосування компресійної еластографії.

Ключові слова - Ультразвукове дослідження, еластографія, желатиновий фантом, діагностика, лінійний датчик, конвексний датчик, внутрішньопорожнинний датчик.

\section{I. ВСТУП}

Еластографія, на сьогодні, $є$ одним із нових методів, який активно застосовується для ранньої діагностики об'ємних патологічних утворень різних органів. Як будьякий новий метод, він потребує детального вивчення. У зв'язку 3 цим, робота $\epsilon$ надзвичайно актуальною.

Компресійна еластографія альтернативою для біопсії, рентгенологічних досліджень та імунологічних досліджень, що дозволяє неінвазивно діагностувати ракові новоутворення, а також проводити моніторинг перебігу процесів в них протягом всього періоду лікування [1,2,3,4,5].

В силу того, що даний метод почали впроваджувати досить недавно, його можливості ще мало досліджені та не структуровані. В даний час, еластографію виконують лише для поверхневих органів за допомогою лінійних датчиків.

Ультразвукова еластографія є методом, в основі якого лежить пропускання звукових хвиль через тканину для визначення іiі еластичності (пружгості). Це дослідження дозволяє діагностувати онкологічні новоутворення на ранніх стадіях без безносереднього втручання в тканини, яке може спровокувати активний ріст ракових клітин. Найбільш часто даний метод використовується для досліджень поверхневих органів, таких як печінка, щитовидна залоза, молочні залози, нирки, простата та лімфатичні вузли. Але в останніх моделях УЗ апаратів функція еластографії реалізована не лише для лінійних датчиків, a i для конвексних та внутрішньопорожнинних також, що дає змогу досліджувати більш глибоко розташовані органи. Саме тому, важливо експериментально визначити вплив глибини на якість діагностики, та встановити доречність використання певного датчика для певного органу. [1]

Еластографія оцінює еластичність тканини, шляхом вимірювання опору, який 
чинить тканина під час деформації від прикладеної сили натиску на поверхню тканини ультразвуковим датчиком. Припускаючи, що матеріал $\epsilon$ абсолютно еластичним і його деформація не залежить від в'язкості, еластичність може бути описана законом Гука. Для деформації розтягу-стиску закон Гука має вигляд [6]:

$$
\sigma=E \varepsilon
$$

де $\sigma$ - нормальне напруження; $E$ - модуль поздовжньої пружності (далі - модуль Юнга); $\varepsilon$ - відносна поздовжня деформація, що дорівнює зміні товщини тканини відносно початкової.

Для ізотропних матеріалів між модулем Юнга $E$, коефіцієнтом Пуассона $\mu$ i модулем пружності при зсуві $G$ існує наступна залежність:

$$
G=\frac{E}{2(1+\mu)}
$$

Об'ємний модуль пружності $K$ при триосьовому деформуванні ізотропного матеріалу з прикладанням однакового тиску, пов'язаний 3 модулем Юнга $E$ співвідношенням:

$$
K=\frac{E}{3(1-2 \mu)}
$$

При одноосьовому деформуванні тіла у замкнутому об'ємі рівняння (3) набуває вигляду:

$$
K=\frac{E}{1-2 \mu}
$$

В результаті ряда перетворень, залежність між модулем Юнга і швидкістю розповсюдження зсувної хвилі набуває вигляду $[6,7]$ :

$$
E=3 \rho c^{2},
$$

де $\rho$ - густина середовища.

\section{II. МЕТА ДОСЛІДЖЕННЯ}

Мета роботи: розширення можливості використання та підвищення ефективності методу еластографії шляхом дослідження впливу частоти сканування i глибини залягання патологічних тканин на інформативність зображення.

\section{III. МАТЕРІАЛИ ТА МЕТОДИ}

Для досягнення поставленої мети було обрано ультразвукову систему Sonoscape P20 3 трьома датчиками: лінійним L742, конвексним 3C-A та внутрішньо порожнинним 6V3 (рис.1).

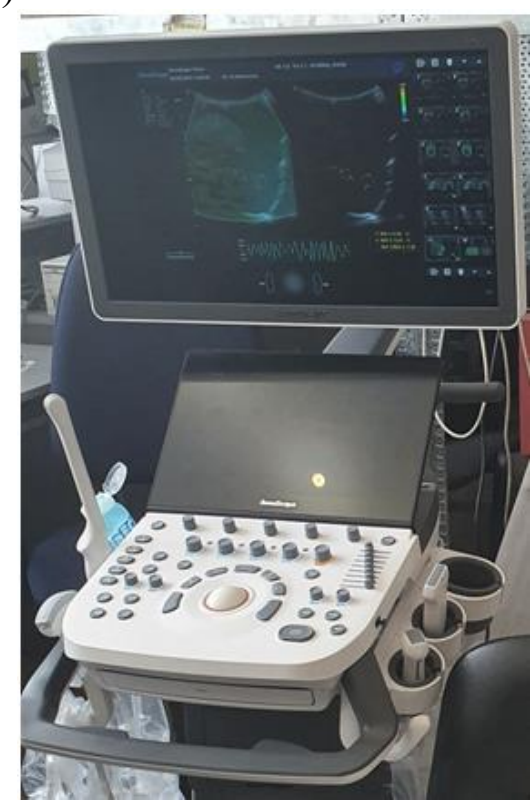

Рис. 1 - Ультразвукова діагностична система SonoScape P20

Для імітації патологічної тканини було обрано три однакові гумові кульки, діаметром $6,5 \mathrm{~cm}$.

Для імітації здорової тканини використовували три фантоми, створені згідно 3 опробованою технологією [8] із желатину та крохмалю.

В першому фантомі (Тіло 1) гумову кульку було розміщено на глибині $4,25 \mathrm{~cm}$; в другого фантомі (Тіло 2) - на глибині 11,75 см; в третьому фантомі (Тіло 3) - на глибині 18,25 см. Відстані відраховувалися від поверхні фантому до центріу мас кульок.

\section{IV. РЕЗУЛЬТАТИ ТА ОБГОВОРЕННЯ}

Кожний 3 трьох датчиків L742, 3C-A, 6V3 застосовувався послідовно для кожного 3 фантомних тіл у трьох частотних режимах. Загальна кількість отриманих зображень склала 27.

Дослідження лінійним датчиком L742 проводилося для трьох тіл, встановлюючи початковий діапазон частот сканування 57 МГц, поступово змінюючи його на 6-8 і 9-13 МГц. 
Для Тіла 1 в діапазоні частот 6-8,5 МГц (рис. 2) спостерігалася чітка диференціація тканин, що дає можливість якісно діагностувати характер новоутворення. Відношення еластичностей становило 3,64, що $\epsilon$ високим показником диференціації, значно відрізняється від одиниці і свідчить про неоднорідність тканин.

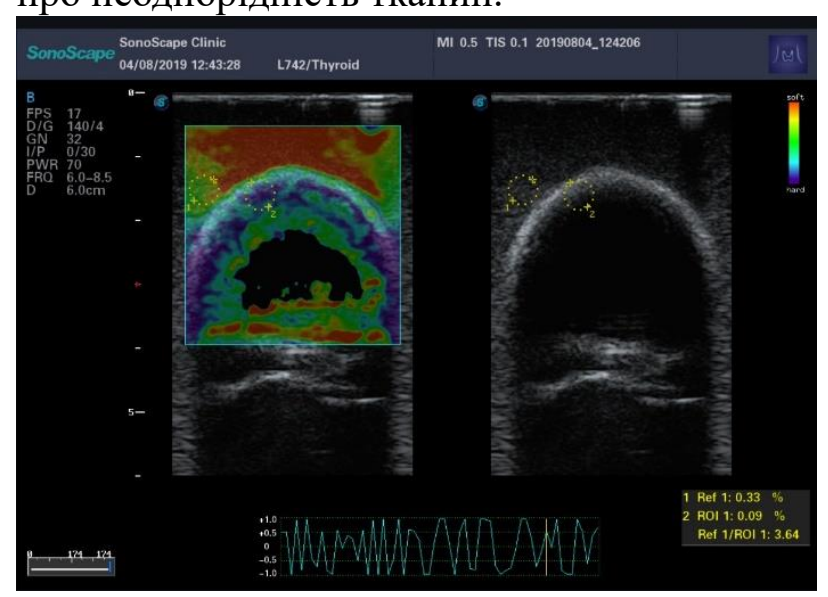

Pис. 2 - Датчик L742, Тіло 1, Частота 6-8,5 МГц

Для Тіла 1 при частотах сканування 913 МГц (рис. 3) спостерігалося зниження якості зображення, диференціація тканин менш чітка, що дає можливість діагностувати характер новоутворення, але не так якісно як в попередньому випадку. Відношення еластичностей становило 3,21 , що $\epsilon$ високим показником диференціації, суттєво відрізняється від одиниці і свідчить про неоднорідність тканин.

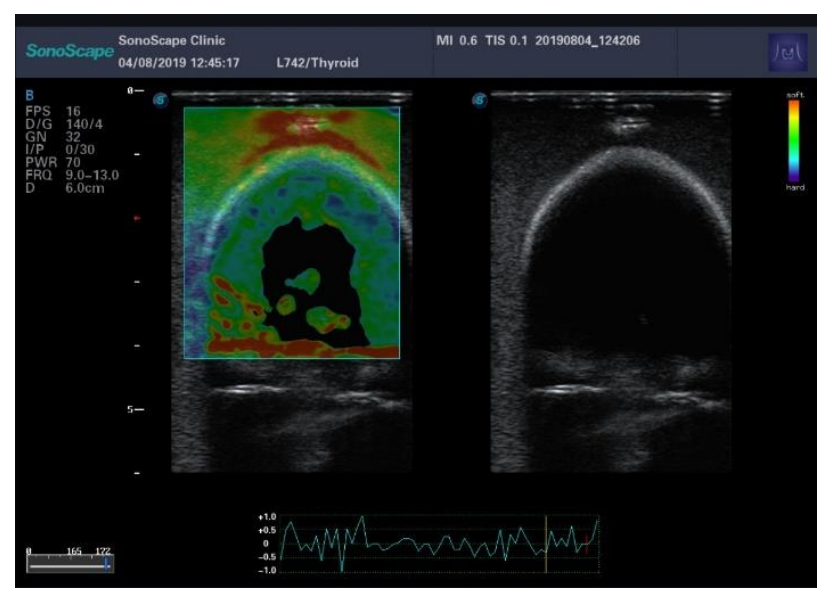

Рис. 3 - Датчик L742, Тіло 1, Частота 9-13 МГц

При діапазоні частот 5-7 МГц спостерігався найменший рівень якості діагностики. Відношення еластичностей становило 2,63, але незважаючи на це, диференціація тканин достатньо чітка для виявлення новоутворень. Отже, найбільш якісне зображенням для Тіла 13 використанням лінійного датчика було отримане при дослідженні, виконаному в середньому діапазоні частот - 6-8,5 МГц.

Дослідження лінійним датчиком L742 були проводені для Тіла 2 і Тіла 3. Отримані зображення для Тіла 2 не несуть чіткої інформації і не можуть бути використані для точної діагностики. Отримані зображення для Тіла 3 не показали жодних результатів, що свідчить про недоцільність еластографії, виконаної лінійним датчиком.

Аналогічні дослідження проводилися конвексним датчиком 3С-А для трьох тіл, встановлюючи початковий діапазон частот сканування 2,4-3,7 МГц, поступово змінюючи його на 4-5,2 і 6-7 МГц.

Для Тіла 1 при частоті 2,4-3,7 МГц (рис. 4) спостерігалася низька якість зображення та диференціація тканин, що не дає можливості достовірно діагностувати характеру новоутворення. Відношення еластичностей в даному випадку становило 2,2, що є показником, нижчим за середній.

Для Тіла 1 при частотах сканування 45,2 і 6-7 МГц рівень якості зображення був достатній для виявлення наявності новоутворення, але не достатній для встановлення його характеру - відношення еластичностей відповідно дорівнювали 1,94 і 2,15 .

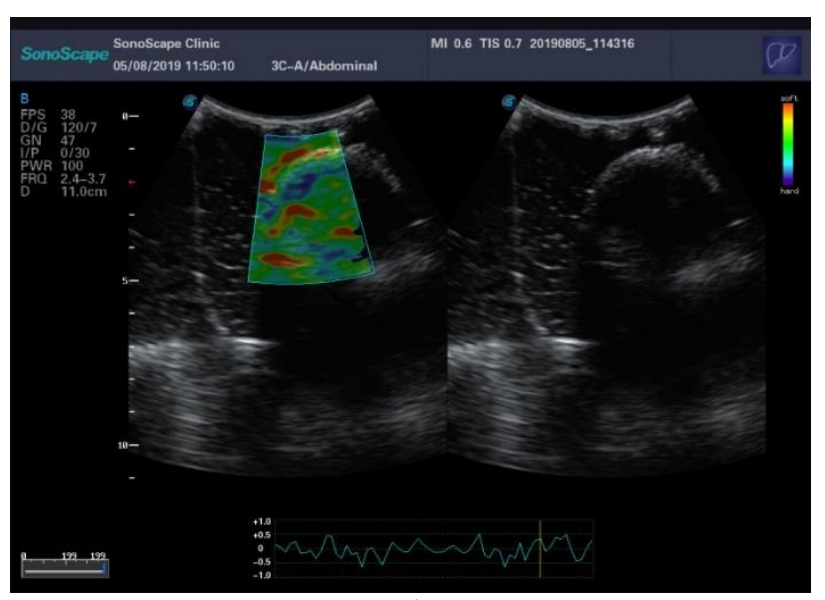

Рис. 4 - Датчик 3С-А, Тіло 1, Частота 2,4 -3,7 МГц

Для Тіла 2 в діапазоні частот 2,43,7 МГц (рис. 5) спостерігалася вища якість зображення та диференціація тканин ніж в аналогічному дослідження для Тіла 1 , але різниця не суттєва, зображення не дає можливості достовірної діагностики характеру 
новоутворення. Відношення еластичностей становило 2,8. При частотах сканування 4-5,2 і 6-7 МГц Тіла 2 рівень якості зображення достатній для виявлення наявності новоутворення, але не достатній для встановлення його характеру.

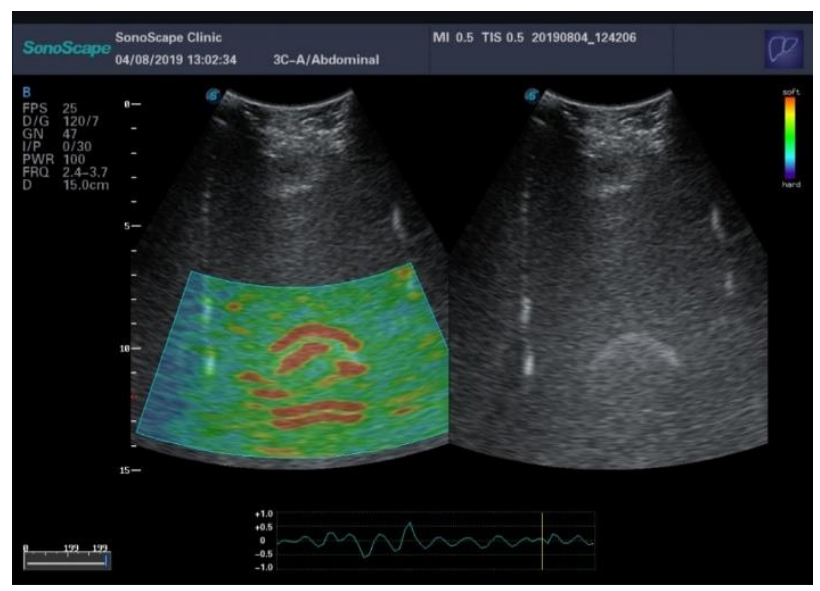

Рис. 5 - Датчик 3С-А, Тіло 2, Частота 2,4 -3,7 МГц

Проведені дослідження Тіла 3 за допомогою конвексного датчика 3С-А в усіх діапазонах частот, показали низький рівень якості діагностики, достатній для виявлення наявності новоутворення, але не достатній для встановлення його характеру. Відношення еластичностей дорівнювали 1,48-1,69.

Аналогічні дослідження проводилися внутрішньопорожнинним датчиком 6V3 для трьох тіл, встановлюючи початковий діапазон частот сканування 3-6 МГц, поступово змінюючи його на 4,5-8,2 і 6,5-10 МГц.

Для Тіла 1 при частоті сканування 3 -6 МГц (рис.6) зображення досить чітке, але еластографія не інформативна, так як немає розмежування кордонів середовищ.

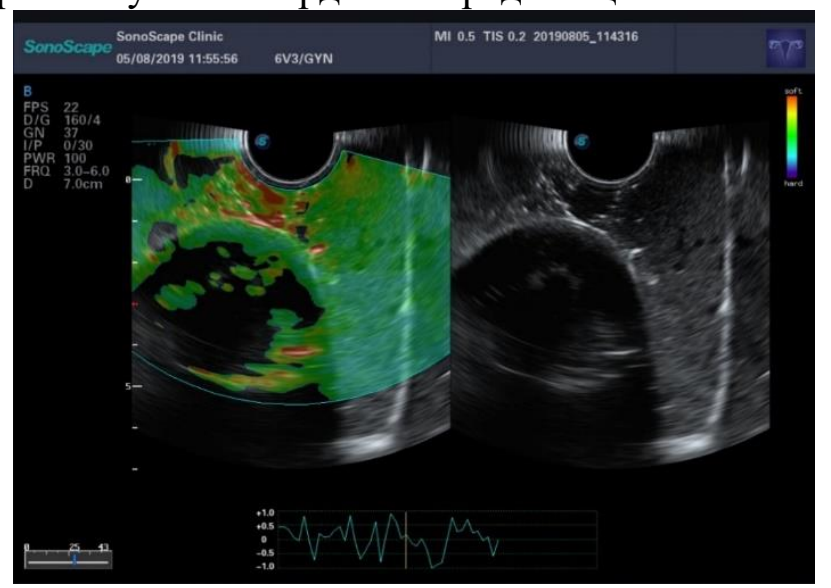

Рис. 6 -Датчик 6V3, Тіло 1, Частота 3 - 6 МГц

Для Тіла 1 при частотах сканування 4,5-8,2 i 6,5-10 МГц відношення еластичностей дорівнювало 1 , що є низьким показником диференціації тканин.

Для Тіла 2 при частотах сканування 3 6 МГц (рис. 7) спостерігалася висока якість зображення та диференціація тканин, що дає можливість достовірно діагностувати наявність та характер новоутворення. Відношення еластичностей в даному випадку становило 4,81, що $\epsilon$, високим показником i говорить про високу якість дослідження тканин.

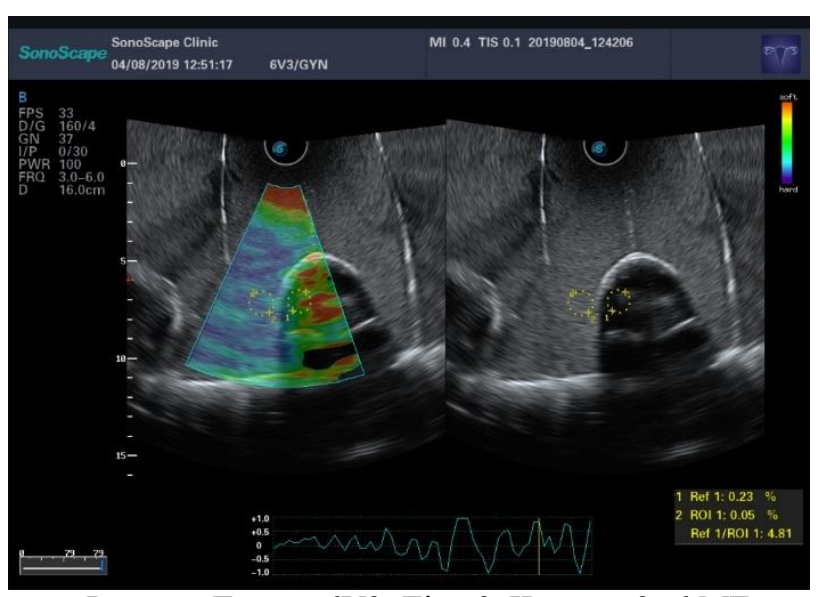

Рис. 7 - Датчик 6V3, Тіло 2, Частота 3 -6 МГц

Дослідження Тіла 2 при частотах сканування 4,5-8,2 МГц і 6,5-10 МГц дали гарний результат і високі відношення еластичностей 3,1 і 3,16 відповідно.

Для Тіла 3, при всіх діапазонах частотах сканування датчиком 6V3, якість зображення низька (рис. 8), диференціація тканин взагалі не спостерігається, що виключає можливість діагностики наявності новоутворення. Відношення еластичностей дорівнювало 1.

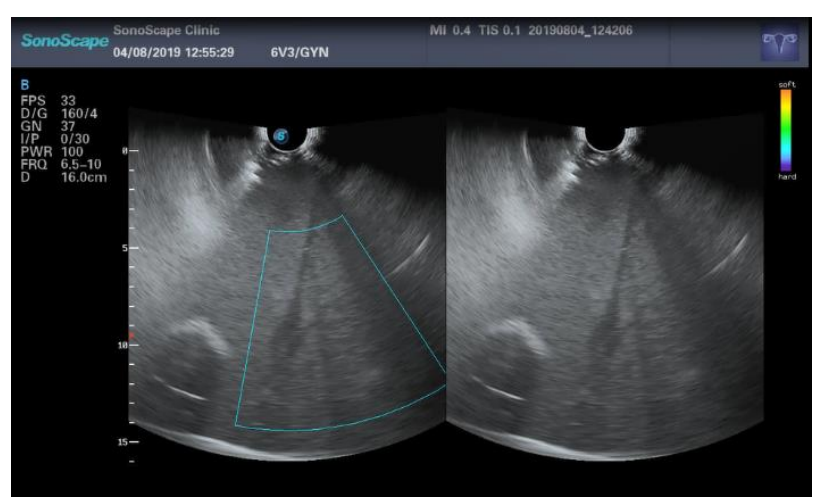

Рис. 8 - Датчик 6V3, Тіло 3, Частота 6,5 - 10 МГц

Найбільш інформативні результати проведених досліджень зведено в таблицю 1 
Таблиця 1 - Аналіз проведених досліджень

\begin{tabular}{|c|c|c|c|}
\hline $\begin{array}{l}\text { Дат- } \\
\text { чик }\end{array}$ & Тіло & $\begin{array}{r}\text { Частота } \\
\text { скануван- } \\
\text { ня, МГц } \\
\end{array}$ & Результат \\
\hline \multirow{6}{*}{ L742 } & \multirow{3}{*}{$\begin{array}{l}\text { Тіло } \\
1\end{array}$} & $5-7$ & $\begin{array}{l}\text { Чітке розмежування } \\
\text { кордонів середовищ }\end{array}$ \\
\hline & & $6-8,5$ & $\begin{array}{l}\text { Найбільш чітке } \\
\text { розмежування кордонів } \\
\text { середовищ }\end{array}$ \\
\hline & & $9-13$ & $\begin{array}{l}\text { Чітке розмежування } \\
\text { кордонів середовищ }\end{array}$ \\
\hline & \multirow[b]{2}{*}{$\begin{array}{l}\text { Тіло } \\
2\end{array}$} & $5-7,1$ & Тіло не відображається \\
\hline & & $6-8,5$ & $\begin{array}{l}\text { Тіло відображається, } \\
\text { але кордони не чіткі, } \\
\text { еластографія не несе } \\
\text { достовірної } \\
\text { інформативності }\end{array}$ \\
\hline & $\begin{array}{l}\text { Тіло } \\
3\end{array}$ & $6-8,5$ & Тіло не відображається \\
\hline \multirow{3}{*}{$3 \mathrm{C}-\mathrm{A}$} & $\begin{array}{l}\text { Тіло } \\
1\end{array}$ & $\begin{array}{l}2,4- \\
3,7\end{array}$ & $\begin{array}{l}\text { Чітке розмежування } \\
\text { кордонів середовищ, } \\
\text { але еластографія не } \epsilon \\
\text { достатньо } \\
\text { інформативною }\end{array}$ \\
\hline & $\begin{array}{l}\text { Тіло } \\
2\end{array}$ & $\begin{array}{l}2,4- \\
3,7\end{array}$ & $\begin{array}{l}\text { Найбільш чітке } \\
\text { розмежування кордонів } \\
\text { середовищ, але } \\
\text { еластографія не } \\
\text { достатньо } \\
\text { інформативна, так як } \\
\text { розмежування } \\
\text { середовищ не досить } \\
\text { чітке }\end{array}$ \\
\hline & $\begin{array}{l}\text { Тіло } \\
3\end{array}$ & $\begin{array}{l}2,4- \\
3,7\end{array}$ & $\begin{array}{l}\text { Результати не чіткі, } \\
\text { еластографія не несе } \\
\text { ніякої інформативності }\end{array}$ \\
\hline \multirow{6}{*}{$6 \mathrm{~V} 3$} & $\begin{array}{l}\text { Тіло } \\
1\end{array}$ & $3-6$ & $\begin{array}{l}\text { Зображення досить } \\
\text { чітке, але еластографія } \\
\text { не інформативна, так як } \\
\text { немає розмежування } \\
\text { кордонів середовищ. }\end{array}$ \\
\hline & \multirow{3}{*}{$\begin{array}{l}\text { Тіло } \\
2\end{array}$} & $3-6$ & $\begin{array}{l}\text { Найбільш чітке } \\
\text { розмежування кордонів } \\
\text { середовищ }\end{array}$ \\
\hline & & $\begin{array}{l}4,5- \\
8,2\end{array}$ & $\begin{array}{l}\text { Чітке розмежування } \\
\text { кордонів середовищ }\end{array}$ \\
\hline & & $6,5-10$ & $\begin{array}{l}\text { Чітке розмежування } \\
\text { кордонів середовищ }\end{array}$ \\
\hline & \multirow{2}{*}{$\begin{array}{l}\text { Тіло } \\
3\end{array}$} & $\begin{array}{l}4,5- \\
8,2\end{array}$ & $\begin{array}{l}\text { Результати не чіткі, } \\
\text { еластографія не несе } \\
\text { ніякої інформативності }\end{array}$ \\
\hline & & $6,5-10$ & $\begin{array}{l}\text { Результати не чіткі, } \\
\text { тому подальша зміна } \\
\text { частот не несе ніякого } \\
\text { сенсу }\end{array}$ \\
\hline
\end{tabular}

Якість еластографії оцінювалася по відношенням еластичностей середовищ, що відображає якість диференціації тканин. Чим значення відношення вище за одиницю, тим вищий показник розмежування кордонів та диференціації тканин досліджуваних тіл [9].

Результати проведених досліджень дали можливість побудувати діаграми якості еластографічного дослідження:

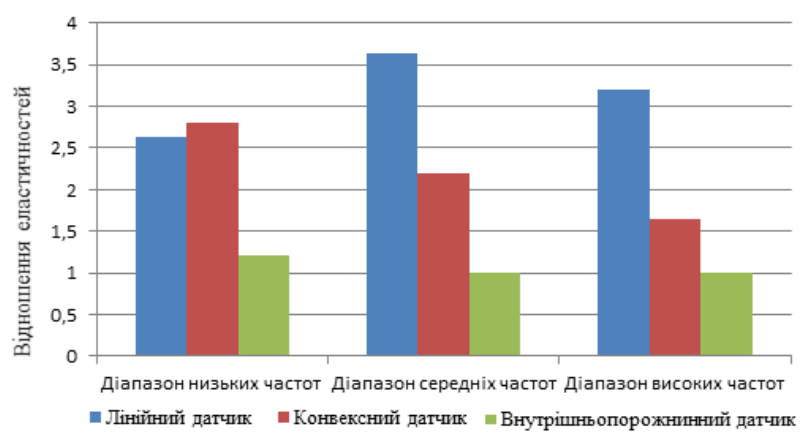

Рис. 9 - Діаграма якості еластографічного дослідження для Тіла 1

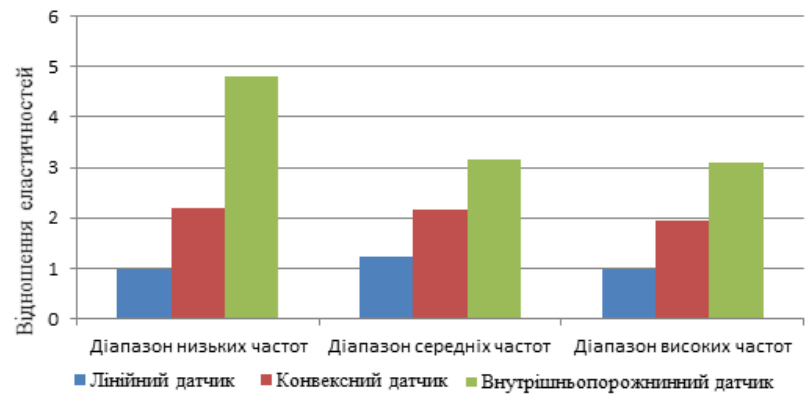

Рис. 10 - Діаграма якості еластографічного дослідження для Тіла 2

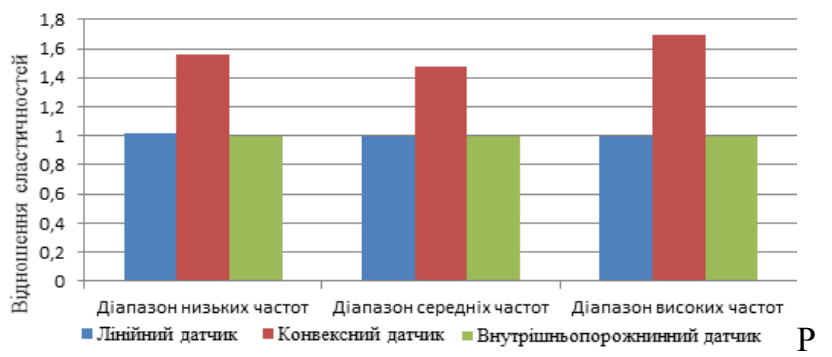

ис. 11 - Діаграма якості еластографічного дослідження для Тіла 3

\section{V. ВИСНОВКИ}

Аналіз побудованих діаграм дозволяє сформлювати висновки:

1. Для Тіла 1 , в якому досліджуваний об'єкт був розміщений на найменшій глибині найкращі результати були отримані за допомогою лінійного датчика L742. Bci результати виявились ефективними, але найякісніше зображення було отримано при роботі датчика на середніх частотах (6-8,5 МГц). 
2. Для Тіла 2, в якому досліджуваний об'єкт був розміщений на середній глибині найбільш оптимальним виявився внутрішньопорожнинний датчик 6V3, при його роботі на низьких частотах, а також можливе використання конвексного датчика 3С-А на середніх частотах.

3. Для Тіла 3, в якому досліджуваний об'єкт був розміщений на найбільшій глибині, для жодного 3 датчиків не було отримано зображення достатньої якості, що говорить про те, що компресійна еластографіє не $\epsilon$ ефективним методом для дослідження глибоко розміщених тіл.

\section{ПЕРЕЛІК ПОСИЛАНЬ}

[1] Гурбатов С.Н. Ультразвукова еластографія: аналітичний опис різних режимів і технологій / С.Н. Гурбатов, І.Ю. Дьомін, Н.В. Прончатов-Рубцов - Н. Новгород: Нижегородський госуніверсітет. -2015. - 115 с.

[2] Котляров П.М., Харченко В.П., Александров Ю.К., Могуньо М.С., Сенча А.Н., Патрун Ю.Н., Бєляєв Д.В. Ультразвукова діагностика захворювань щитовидної залози. М .: ВІДАР, 2017. - 239 с.
[3] Головко Т. С. Комплексне ультразвукове дослідження із застосуванням еластографії для виявлення рецидиву у хворих на рак шийки матки [Електронний ресурс] / Т. С. Головко, В. С. Іванкова. - 2016. - Режим доступу до ресурсу: https://www.clinicaloncology.com.ua/article/15490/kompleksneultrazvukove-doslidzhennya-iz-zastosuvannyam-elastografii-dlyaviyavlennya-recidivu-u-xvorix-na-rak-shijki-matki.

[4] Ультразвукова еластографія молочної залози: первинне дослідження [Електронний ресурс]. - 2018. - Режим доступу до ресурсу: https://rh.org.ru/statti/ultrazvukovaya-elastografiyamolochnoj-zhelezy-pervichnoe-issledovanie/.

[5] Shiina T., Nightingale K.R., Palmeri M.L. et al. WFUMB Guidelines and Recommendations for Basic Principles and Terminology // Ultrasound Med. Biol. 2015.V.41.No. 5. P. 11261147.

[6] Писаренко Г.С., Квітка О.Л., Уманський Е.С. Опір матеріалів: Підручник / За ред. Г.С. Писаренка. — К.: Вища школа, 1993. - 655 с.

[7] Осипов Л. В. Технології еластографії в ультразвуковій діагностиці [Електронний ресурс] / Л. В. Осипов. - 2016. Режим доступу до ресурсу: http://izomed.ru/files/000032.pdf [8] Фантом для занять [Електронний ресурс]. - 2016. - Режим доступу до ресурсу: rsra.rusanesth.com〉 assets〉 files> presentations > fantom.

[9] Лазебник Л.Б. Діагностична значимість ультразвукової еластометріi / Л.Б. Лазебник, Е.В. Вінницька, Н.А. Шапошникова, С.Г. Хмарка, А.В. Ніканоров, А.А. Терьохін, М.М. Воробйова, Е.В. Голованова Е.В. // Експериментальна та клінічна гастроентерологія.-2010.-№5.-с.10-13.

\title{
УДК 534.642
}

\section{МЕТОД ОЦЕНКИ ЭФФЕКТИВНОСТИ КОМПРЕССИОННОЙ ЭЛАСТОГРАФИИ БИОЛОГИЧЕСКИХ ТКАНЕЙ В ЗАВИСИМОСТИ ОТ ГЛУБИНЫ ИХ РАСПОЛОЖЕНИЯ}

\author{
Мищенко Ю.С., магистрант \\ sokol7romashka@gmail.com \\ Факультет биомедицинской инженерии \\ Национального технического университета \\ «Киевский политехнический институт имени Игоря Сикорского», \\ г. Киев, Украина \\ Тарасова Л.Д., доц., к.Т.н. \\ larisa.tarasova.dmitrievna@gmail.com \\ Кафедра биомедицинской инженерии \\ Национального технического университета \\ «Киевский политехнический институт имени Игоря Сикорского», \\ г. Киев, Украина
}

Реферат - Предложен метод оценки эффективности компрессионной эластографии биологических тканей в зависимости от глубины их расположения, который позволяет исследовать качество изображсения и дифференциачию тканей от глубины размещения тест-объекта, типа датчиков и диапазона частот сканирования. Полученные данные розщиряют возможности применения компрессионной эластографии.

Ключевые слова - Ультразвуковое исследование, эластография, желатиновый фантом, диагностика, линейный датчик, конвексный датчик, внутриполостной датчик. 


\section{METHOD FOR THE ESTIMATING EFFICIENCY OF COMPRESSION ELASTOGRAPHY OF BIOLOGICAL TISSUES, DEPENDING ON THE DEPTH OF THEIR LOCATION}

Mishchenko Y.S., Master sokol7romashka@gmail.com National Technical University of Ukraine "Igor Sikorsky Kyiv Polytechnic Institute", Kiev, Ukraine

тарасова Л.Д., Associate Professor, Ph.D. larisa.tarasova.dmitrievna@gmail.com Department of Biomedical Engineering National Technical University of Ukraine "Igor Sikorsky Kyiv Polytechnic Institute", Kiev, Ukraine

Abstract - A method is proposed for evaluating the effectiveness of compression elastography of biological tissues depending on the depth of their location, which allows one to study image quality and tissue differentiation from the depth of placement of the test object, the type of sensors and the range of scanning frequencies. The data obtained expand the possibilities of using compression elastography. 